\title{
Influence of Cry1Ac Toxin From Bt Cotton on the Soil Microbiota
}

\author{
Marcos Gino Fernandes ${ }^{1,2}$, Renata Pires de Araújo ${ }^{1}$, Eduardo Neves Costa ${ }^{2}$, \\ Ana Claudia Terumi Abe Zangirolymo ${ }^{1} \&$ Rodrigo Matheus Pereira ${ }^{1}$ \\ ${ }^{1}$ Programa de Pós-graduação em Entomologia e Conservação da Biodiversidade, Faculdade de Ciências \\ Biológicas e Ambientais, Universidade Federal da Grande Dourados, Dourados, MS, Brazil \\ ${ }^{2}$ Programa de Pós-graduação em Agronomia, Faculdade de Ciências Agrárias, Universidade Federal da Grande \\ Dourados, Dourados, MS, Brazil \\ Correspondence: Eduardo Neves Costa, Programa de Pós-graduação em Agronomia, Faculdade de Ciências \\ Agrárias, Universidade Federal da Grande Dourados, Dourados, MS, Brazil. Tel: 55-679-8124-9453. E-mail: \\ costa_ne@yahoo.com.br
}

Received: October 30, 2018

Accepted: January 24, 2019 Online Published: March 15, 2019

doi:10.5539/jas.v11n4p364

URL: https://doi.org/10.5539/jas.v11n4p364

\begin{abstract}
The first record of transgenic cotton cultivation in Brazil was in 2005, of that of the cultivar MON 531, possessing the $c r y 1 A c$ gene. Since then, no evaluation has been performed to understand whether the cultivation of $B t$ cotton has caused any interference with the soil microbiota, including bacteria. In this context, our research was aimed to assess whether the cultivation of $B t$ cotton negatively affects the community of soil bacteria, through quantitative and metagenomic analyses (marker gene 16S rRNA) for phylum identification. Samples of bacterial populations obtained from the soil cultivated with $B t$ cotton expressing the CrylAc toxin were compared with soil samples from the area cultivated with conventional cotton. Significant differences were not observed in the measure of colony-forming units of bacteria between the soils cultivated with $B t$ and non- $B t$ cotton; however, differences were detected only when comparing samples from different collection times of the $B t$ treatment. Cultivation of $B t$ cotton did not affect the diversity of the soil bacterial population. Overall, our study shows that, similar to most of the works that have been reported worldwide, cultivation of transgenic cotton does not seem to affect the quantity and diversity of natural soil bacteria.
\end{abstract}

Keywords: $B t$ cotton, Gossypium hirsutum L., metagenome, soil microbiota, microbiology ecology, 16S rRNA

\section{Introduction}

Genetically modified plants (GMPs) or transgenic plants originate from recombinant DNA technology. This involves the insertion of foreign genes in their genome, which may be derived from various sources such as microorganisms, animals, or plants (Monnerat \& Bravo, 2000). In agriculture, transgenics have been employed with the aim of expressing genes in plants that can confer resistance to insect pests (Zhu et al., 2012) and pathogens (Sarowar et al., 2009), in addition to imparting herbicide tolerance (Benekos et al., 2010).

The most common molecular strategy for the generation of transgenic plants resistant to insects is developed using genes that encode insecticidal proteins of the entomopathogenic bacterium Bacillus thuringiensis (Berliner 1915; Bacillales: Bacillaceae), popularly referred to as Bt (Fischhoff, 1987). With the adoption of this strategy, the $B t$ gene has been incorporated into the genome of several plant species such as soybean (Glycine max L. Merr.; Fabales: Fabaceae), maize (Zea mays L.; Cyperales: Poaceae), cotton (Gossypium hirsutum L.; Malvales: Malvaceae), rice (Oryza sativa L.; Cyperales: Poaceae), and canola (Brassica napus L.; Brassicales: Brassicaceae) (Guerrante, 2003; Pinto \& Fiuza, 2008).

The first report on cultivation of transgenic cotton in Brazil was in 2005, of that of the cultivar MON 531, that possesses the $c r y 1 A c$ gene. Since then, other Bt cotton cultivars have been developed for controlling of several pests of this crop, such as Pectinophora gossypiella (Saunders; Lepidoptera: Gelechiidae), Helicoverpa zea (Boddie; Lepidoptera: Noctuidae), Heliothis virescens (F.; Lepidoptera: Noctuidae), Spodoptera frugiperda (J. E. Smith; Lepidoptera: Noctuidae), and Anthonomus grandis (Boheman; Coleoptera: Curculionidae) (Bommireddy \& Leonard, 2008; Martins et al., 2008; Wu, Lu, Feng, Jiang, \& Zhao, 2008).

Different research studies have been performed in the past with the objective of solving many negative effects triggered with the advent of transgenic plants resistant to insects, such as the evolution of pests that are resistant 
to $B t$ toxins (Tabashnik, Brévault, \& Carrière, 2013), negative effects on natural enemies (Lövei, Andow, \& Arpaia, 2009), and the possible negative effects on beneficial microorganisms present in the agroecosystems (Cheeke, Darby, Rosenstiel, Bever, \& Cruzan, 2014). However, studies that approach the effects of transgenic plants on bacteria that constitute the soil microbiota are scarce.

The structural diversity of bacterial communities has been studied using methods based on the investigation of a part of their DNA sequence, such as the 16S rDNA. These methods involve the amplification of the 16S rDNA by PCR and posterior characterization through cloning and sequencing, or analysis by electrophoresis, using techniques such as amplified ribosomal DNA restriction analysis (ARDRA), terminal restriction fragment length polymorphism (T-RFLP), random amplified polymorphic DNA (RAPD), ribosomal intergenic spacer analysis (RISA), denaturing gradient gel electrophoresis (DGGE)/temperature gradient gel electrophoresis (TGGE), and single-strand conformation polymorphism (SSCP). This results in obtaining data regarding the relatedness of the bacterial species that constitute the microbial community (Ranjard et al., 2000; Kozdrój \& Van Elsas, 2001).

Molecular methods for the analysis of the structure and diversity of microbes have been developed in the past that utilize the genomic DNA directly extracted from environmental samples. Such developments have allowed considerable advances to be made in the study of microbial ecology (O'Donnell \& Göres, 1999; Ranjard et al., 2000). These techniques enable the identification of factors employed in soil management that interfere with the multiple functions and habitats of the microbial community (Peters, Koschinsky, Schwieger, \& Tebbe, 2000). These methods help in the detailed characterization of the microbial structure and their succession in agricultural soils, including that of the non-cultivable microorganisms (Hugenholtz, Pitulle, \& Pace, 1998), and allow for the identification of predominant species, that may be used as indicators of soil functionality and quality (O'Donnell \& Göres, 1999).

This research was designed to evaluate whether the cultivation of transgenic cotton resistant to insects $(B t)$ affects the community of soil bacteria, either quantitatively or qualitatively. The evaluation was carried out through quantitative analysis of total bacteria and metagenomic analysis of the samples using the marker gene 16S rRNA for species identification. For this purpose, we compared samples of bacterial populations obtained from soil cultivated with $B t$ cotton expressing the Cry1Ac toxin with samples from areas cultivated with conventional cotton. To the best of our knowledge, this is the first report on the effects of $B t$ transgenic cotton on the soil bacterial community in Brazil.

\section{Materials and Methods}

\subsection{Characterization of Cultivation Area}

The studies were conducted in the agricultural area of the experimental farm of Federal University of Grande

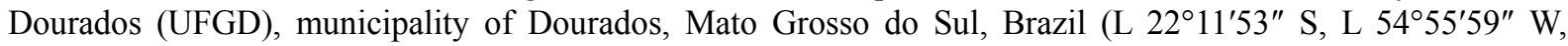
altitude: $430 \mathrm{~m}$ ). The climate, according to data obtained from Brazilian Agricultural Research Corporation (Embrapa) was Cwa (humid mesothermic climate with warm summer and dry winter; the temperature of the coldest period, June and July, is lower than $18{ }^{\circ} \mathrm{C}$, and the temperature of the warmest month, January, is higher than $22^{\circ} \mathrm{C}$ ). In addition, the rainfall in the summer months is 10 -fold higher than the monthly rainfall of July (Fietz \& Fisch, 2008).

According to Thornthwaite climatic classification, the region of Dourados is subhumid, with low water deficit. With respect to the thermal index, the climate is considered megathermal (Fietz \& Fisch, 2008).

The predominant soil type of the region is dystroferric Red Latosol, however, other soil types are also found including Red Argisol and Quartzeneic Neosols. The dystroferric Red Latosol shows clayey texture and natural variable fertility, besides average texture and alic character; however, it is deep, friable, and with great homogeneity along the whole profile (Table 1). The nature of the relief is between flat to soft wave. The vegetal cover consists primarily of pasture and arable land found in the region of Floresta Estacional Semidecidual and the savannah region (Embrapa, 2006). 
Table 1. Number (CFU's) of total soil bacteria observed in cultivation of $B t$ and non- $B t$ cotton by replicate and mean

\begin{tabular}{|c|c|c|c|c|c|c|c|}
\hline Soil & Dilution & Collection Time & Rep 1 & Rep 2 & Rep 3 & Mean $1^{\S}$ & Mean $2^{\pi}$ \\
\hline & & & --------------. & - CFU/mL - & -------------. & & \\
\hline \multirow[t]{6}{*}{$B t$} & $10^{-2}$ & 0 D.A.S. & $2.75 \times 10^{-5}$ & $3.0 \times 10^{-5}$ & $2.5 \times 10^{-5}$ & $2.75 \times 10^{-5} \mathrm{Aa}$ & \\
\hline & $10^{-2}$ & 30 D.A.S. & $2.5 \times 10^{-5}$ & $2.0 \times 10^{-5}$ & $1.8 \times 10^{-5}$ & $2.10 \times 10^{-5} \mathrm{Aab}$ & \\
\hline & $10^{-2}$ & 60 D.A.S. & $2.9 \times 10^{-5}$ & $2.9 \times 10^{-5}$ & $2.0 \times 10^{-5}$ & $2.60 \times 10^{-5} \mathrm{Aab}$ & \\
\hline & $10^{-2}$ & 90 D.A.S. & $1.7 \times 10^{-5}$ & $1.9 \times 10^{-5}$ & $1.9 \times 10^{-5}$ & $1.83 \times 10^{-5} \mathrm{Ab}$ & \\
\hline & $10^{-2}$ & 120 D.A.S. & $2.0 \times 10^{-5}$ & $2.1 \times 10^{-5}$ & $2.1 \times 10^{-5}$ & $2.07 \times 10^{-5} \mathrm{Aab}$ & \\
\hline & $10^{-2}$ & 150 D.A.S. & $2.7 \times 10^{-5}$ & $2.9 \times 10^{-5}$ & $2.9 \times 10^{-5}$ & $2.83 \times 10^{-5} \mathrm{Aa}$ & $2.36 \times 10^{-5} \mathrm{a}$ \\
\hline \multirow[t]{6}{*}{ Non- $B t$} & $10^{-2}$ & 0 D.A.S. & $2.7 \times 10^{-5}$ & $1.3 \times 10^{-5}$ & $2.5 \times 10^{-5}$ & $2.17 \times 10^{-5} \mathrm{Aa}$ & \\
\hline & $10^{-2}$ & 30 D.A.S. & $2.6 \times 10^{-5}$ & $1.7 \times 10^{-5}$ & $3.0 \times 10^{-5}$ & $2.43 \times 10^{-5} \mathrm{Aa}$ & \\
\hline & $10^{-2}$ & 60 D.A.S. & $2.4 \times 10^{-5}$ & $1.7 \times 10^{-5}$ & $1.5 \times 10^{-5}$ & $1.87 \times 10^{-5} \mathrm{Aa}$ & \\
\hline & $10^{-2}$ & 90 D.A.S. & $1.4 \times 10^{-5}$ & $2.2 \times 10^{-5}$ & $2.1 \times 10^{-5}$ & $1.90 \times 10^{-5} \mathrm{Aa}$ & \\
\hline & $10^{-2}$ & 120 D.A.S. & $2.3 \times 10^{-5}$ & $2.1 \times 10^{-5}$ & $1.5 \times 10^{-5}$ & $1.97 \times 10^{-5} \mathrm{Aa}$ & \\
\hline & $10^{-2}$ & 150 D.A.S. & $2.6 \times 10^{-5}$ & $2.9 \times 10^{-5}$ & $2.2 \times 10^{-5}$ & $2.57 \times 10^{-5} \mathrm{Aa}$ & $2.15 \times 10^{-5} \mathrm{a}$ \\
\hline
\end{tabular}

Note. Number of CFUs of bacteria in given volume $(0.1 \mathrm{~mL})$ in days after sowing (D.A.S.), from December 2009 to May 2010, with the means of three plots each of an area of cultivation of genetically-modified cotton $(B t)$ and an area of cultivation of conventional cotton (non- $B t)$. The means followed by the same letter in the columns are not significantly different (Tukey $\alpha=0.05$ ). ${ }^{\S}$ Time collection mean (uppercase letters are comparing $B t$ with non- $B t$ treatment; lowercase letters are comparing collection times within $B t$ or non- $B t$ treatment); ${ }^{\circledR} B t$ and non- $B t$ means.

\subsection{Sowing of the Bt and Non-Bt Cotton Cultivars}

Two sample cultivation areas of $5000 \mathrm{~m}^{2}$ each were prepared in the agricultural region of the Experimental Farm of UFGD, where the $B t$ and non- $B t$ cotton cultivars were sowed. The $B t$ cotton treatment was represented by the transgenic cultivar NuOpal (Bollgard ${ }^{\mathbb{B}}$ I Evento 531), expressing the CrylAc toxin, and the conventional treatment (without the foreign gene) by its isoline, the cultivar Delta Opal ${ }^{\mathbb{R}}$. The aforementioned cultivars display similar agronomic characteristics.

Sowing in both fields was performed on December 31, 2009, with a density of 10 to 14 seeds per linear meter and with line spacing of 0.90 meters. The adopted cultivation methods were based on the agricultural practices recommended by Embrapa (2001), and in both the areas, there was no application of fungicide or insecticide. The no-tillage system was adopted, and millet (Pennisetum glaucum L.; Cyperales: Poaceae), BRS $1501^{\circledR}$ cultivar, was the antecessor crop.

\subsection{Sampling Methodology}

Sample collection was carried out on a monthly basis, totaling six evaluations, the first being carried out one day before sowing (zero day: O D), the second at 30 days after sowing (D.A.S.), the third at 60 D.A.S., the fourth at 90 D.A.S., the fifth at 120 D.A.S., and the sixth at 150 D.A.S. The first collection, performed one day before sowing, was aimed to determine the chemical and microbial characteristics of the soils before sowing the cotton cultivars. Collections of soil samples were performed between the months of December 2009 and May 2010.

One part of the collected samples was brought to the Laboratory of Soils of College of Agricultural Sciences of UFGD for granulometric physical analysis and measurement of $\mathrm{pH}$ and amount of micro and macronutrients (Appendix A: supplementary of Table 1, Online Resource 1).

A second part of the samples was brought to the Laboratory of Microbiology of College of Biological and Environmental Sciences of UFGD to perform quantitative bacterial analysis. In addition, a third part of the samples was brought to the Laboratory of Biochemistry of Microorganisms and Plants of São Paulo State University (UNESP/FCAV), Jaboticabal Campus, to accomplish the metagenomic analysis. The soil samples were collected in three replicates, with the aid of a soil auger, Dutch type, 0 to $15 \mathrm{~cm}$ depth. These samples were conditioned in plastic bags placed inside a styrofoam box under environmental conditions, to maintain their humidity content (Pereira, Neves, \& Drozdowicz, 1996). In the laboratories, the soil samples were preserved under refrigeration for up to $24 \mathrm{~h}$ for posterior analysis of physical and chemical parameters of the soils and their microbiota. Thereafter, the soil samples were sieved using a 2 mm-mesh sieve (Olsen \& Bakken, 1987). 


\subsection{Quantitative Evaluation of the Bacterial Population}

To evaluate the bacterial population, $10 \mathrm{~g}$ of soil was added into Erlenmeyer flasks containing $90 \mathrm{~mL}$ of saline solution $\left(10^{-1}\right.$ dilution) and this initial suspension was vigorously shaken for $5 \mathrm{~min}$. From this suspension, $1 \mathrm{~mL}$ was transferred into an assay tube containing $9 \mathrm{~mL}$ of saline suspension, and the mixture was manually homogenized. This process was repeated until a $10^{-7}$ dilution was obtained (protocol adapted from Neder, 1992). Thereafter, $0.1-\mathrm{mL}$ aliquots of each dilution were transferred by the surface plating method onto Petri dishes containing bacterial culture medium. These dishes were covered by paper film to avoid contamination and drying of the culture medium (Olsen \& Bakken, 1987; Sorheim, Torsvik, \& Goksoyr, 1989) and incubated in a bacteriological oven at $25^{\circ} \mathrm{C}$. Bacterial counting was carried out at $48 \mathrm{~h}$ after inoculation, and for this counting process the Thorton (1922) medium was selected, which is specific to bacterial enumeration (Sorheim et al., 1989).

A completely randomized design was adopted, in factorial scheme with three replicates, comprised the dilution factors and days after sowing (D.A.S.), aiming to compare variance estimates in the samples from different sowing months and before sowing.

\subsection{Characterization of the Bacterial Community}

The extraction of DNA from the soil samples pertaining to the soil collected at 150 D.A.S. was performed using FastDNA ${ }^{\circledR}$ SPIN Kit (MP Biomedicals, Santa Ana, USA; Bio 101; catalog \# 6560-200). The metagenomic DNA, after extraction and quantification, was amplified by PCR using specific primers-fD1: (5'-AGAGTTTGATCCTGGCTCAG-3') and rD1: (5'-AAGGAGGTGATCCAGCC-3') - that amplify the 16S rDNA region (Weisburg, Barns, Pelletier, \& Lane, 1991). PCR was performed according to the methodology described by Pereira et al. (2006) and Silveira et al. (2006). Each $50 \mu \mathrm{L}$ PCR mixture contained $10 \mathrm{ng}$ of soil metagenomic DNA, $1 \mathrm{X}$ buffer $\left(20 \mathrm{mmol} \mathrm{L}^{-1}\right.$ Tris- $\left.\mathrm{HCl}, \mathrm{pH} 8.4 ; 50 \mathrm{mmol} \mathrm{L}^{-1} \mathrm{KCl}\right), 200 \mathrm{mmol} \mathrm{L}^{-1}$ of each dNTP, 2 $\mathrm{mmol} \mathrm{L}^{-1} \mathrm{MgCl}_{2}, 1.25 \mathrm{U}$ Taq DNA Polymerase (Invitrogen ${ }^{\mathrm{TM}}$, São Paulo, Brazil), and 5 pmol of each primer. The PCR was carried out using a thermocycler model PTC-200 and consisted of an initial cycle of $94{ }^{\circ} \mathrm{C}$ for 5 min, followed by 35 cycles of $94{ }^{\circ} \mathrm{C}$ for $30 \mathrm{sec}$ (denaturation of the DNA strands), $56{ }^{\circ} \mathrm{C}$ for $40 \mathrm{sec}$ (annealing), $72{ }^{\circ} \mathrm{C}$ for $90 \mathrm{sec}$ (extension), and a final cycle of $72{ }^{\circ} \mathrm{C}$ for $15 \mathrm{~min}$. The generated amplicons were confirmed by electrophoresis in an $1 \%$ agarose gel containing $0.5 \mu \mathrm{g} \mathrm{mL}^{-1}$ of ethidium bromide, TBE buffer (Tris $89 \mathrm{mmol} \mathrm{L}^{-1}$, $89 \mathrm{~mol} \mathrm{~L}^{-1}$ of boric acid, and $2.5 \mathrm{mmol} \mathrm{L}^{-1}$ of EDTA; $\mathrm{pH} 8.3$ ), and the gel was visualized by using the photo documentation system Gel Doc 2000 (Bio-Rad, Hercules, USA) with UV light.

\subsection{Cloning}

The PCR products amplified in both the sample sets were cloned into the vector pJET1.2/blunt using the cloning kit Clone Jet (ThermoFisher, Waltham, USA; Fermentas; catalog \#K1231) and used for the transformation of the cells of Escherichia coli strain DH5a, which were cultivated in a dish containing Luria Bertani medium supplemented with ampicillin $\left(100 \mu \mathrm{g} \mathrm{mL}^{-1}\right)$. After the cultivation of the transformed clones, the plasmid DNA was isolated by miniprep (Saitou \& Nei, 1987).

\subsection{Sequencing}

The partial sequencing of the gene 16S rRNA was carried out according to the methodology described by Pereira et al. (2006) and Silveira et al. (2006). Thus, the sequencing of each clone was done using $0.4 \mathrm{~mL}$ of DNA Sequencing-Big Dye Terminator reagent in the Cycle Sequencing-ready ABI Prism (version 3); 3.2 pmols M13/pUC 1211 forward initiator oligonucleotide (5'-GTAAAACGACGGCCAGT-3'); 100 ng of plasmid DNA; $4.6 \mathrm{~mL}$ of buffer ( $400 \mathrm{mM}$ Tris- $\mathrm{HCl} \mathrm{pH} \mathrm{9;} 10 \mathrm{mM} \mathrm{MgCl}_{2}$ ); and $\mathrm{H}_{2} \mathrm{O}$ milli-Q (Millipore) for a volume of $10 \mu \mathrm{L}$. The reaction was placed in a thermocycler model PTC-200, with a cycle of two minutes at $96^{\circ} \mathrm{C}$ and then submitted to 40 cycles of $96{ }^{\circ} \mathrm{C}$ for $10 \mathrm{sec}, 52{ }^{\circ} \mathrm{C}$ for $20 \mathrm{sec}$, and $60{ }^{\circ} \mathrm{C}$ for $4 \mathrm{~min}$. The amplicons were sequenced using a capillary sequencer (model ABI 3700, Applied Biosystems, Foster City, USA). After sequencing the samples, the gel image was analyzed using the Sequencing Analysis 3.4 software that generated the electropherograms of the sequences.

\subsection{Phylogenetic Analysis and Comparison of the Libraries}

The electropherograms were submitted to the software package Phred/Phrap/Consed (Gordon, Abajian, \& Green, 1998) to verify the sequence quality and the presence of chimeric DNA. The sequences were compared with sequences in the Ribosomal Database Project (RDP) (http://rdp.cme.msu.edu/) using the software Seqmath (Dunbar, Takala, Barns, Davis, \& Kuske, 1999).

Phylogenetic trees were built from the sequencing of 371 sequences with the aid of the program ClustalW, for global alignment of the sequences, and then performed with the aid of the software Mega 5.0. Thereafter, the 
aligned file was used for phylogenetic rebuilding, using the Neighbor-joining method. The model of nucleotides replacement used was that of Jukes-cantor, and the bootstrap phylogeny test was run 1000 times.

\subsection{Statistical Analyses}

To check whether the bacterial population density differed between the cotton cultivars and between the collection months, the two-way analysis of variance (ANOVA) method was used, considering the interaction between the dilution factors $\times$ D.A.S. Subsequently, the mean values were compared by Tukey's test $(\alpha=0.05)$.

We used the indexes of Simpson and Shannon to calculate the diversity index, and for the calculation of the dominance index, we employed Simpson's index. These indexes were calculated using the software DivEs (Rodrigues, unpublished data).

\section{Results and Discussion}

\subsection{Quantitative Evaluation of the Bacterial Population}

Significant differences were not observed concerning the number of colony-forming units (CFUs) of bacteria between the soils cultivated with $B t$ or non-Bt cotton $(F=2.12$; $\mathrm{df}=1,34 ; P=0.16$; Table 1). Earlier research conducted to investigate effects of the cultivation of transgenic maize and cotton resistant to insects $(B t)$ on the population of several soil microorganisms did not show significant effects (Flores, Saxena, \& Stotzky, 2005; Shen, Cai, \& Gong, 2006; Icoz, Saxena, Andow, Zwahlen, \& Stotzky, 2008; Hu et al., 2009; Li et al., 2011), corroborating our findings in the current study. Significant differences were also not found regarding the interaction between cotton cultivar and days after sowing (D.A.S.) $(F=3.57 ; \mathrm{df}=5,12 ; P>0.05$; Table 1$)$.

However, there were significant differences detected in the quantity of bacteria in the $B t$ soil when comparing the collections from different D.A.S. $(F=6.41 ; \mathrm{df}=5,12 ; P=0.004)$ (Table 1). These results are in accordance with those shown by $\mathrm{Li}$ et al. (2011), in which the cultivation of transgenic cotton resistant to insects (Cry1 Ac) for three consecutive years, caused fluctuation in the number of CFUs in the different assessment periods (months and years), but this occurred due to seasonal factors, not being associated with the $B t$ toxin. Similarly, Rui et al. (2005) did not find significant variations when evaluating different concentrations of $B t$ toxin in the rhizosphere of genetically modified cotton and its influence on the soil bacteria. These authors had shown that the cultivation of $B t$ cotton did not significantly affect the number of soil bacteria throughout the study, consistent with our research, with differences noted only between the collection months.

\subsection{Characterization of the Bacterial Community}

To investigate the possible effects of GMPs on the soil bacterial community, this work evaluated a total of 371 clones that were partially sequenced and belonged to two metagenomic libraries: a $B t$ library, constituted by 181 clones, and another non- $B t$ library, composed of 190 clones. Libraries of both treatments were compared with sequences in the RDP. To compare the libraries, the data were normalized wherever there were differences concerning the number of clones between cultivars. From the 181 sequences of the $B t$ library, 11 phyla were detected within the Archaea and Bacteria domains. Of these, $8 \%$ belonged to phylum Actinobacteria; $1.1 \%$ Bacteroidetes; 0.5\% Chloroflexi; 3\% Crenarchaeota; 0.3\% Deinococcus-Thermus; 2.7\% Euryarchaeota; 3\% Firmicutes; $0.3 \%$ Gemmatimonadetes; $27.5 \%$ Proteobacteria; $0.5 \%$ Spirochaetes; $0.8 \%$ Thermotogae; and 1.3\% did not group to any phylum (Figure 1). In the non- $B t$ library, 13 phyla were registered within the Archaea and Bacteria domains. Of these, $0.3 \%$ belonged to the phylum Acidobacteria; $7.5 \%$ Actinobacteria; $0.3 \%$ Aquificae; 0.3\% Bacteroidetes; 0.5\% Crenarchaeota; 0.3\% Euryarchaeota; 3.5\% Firmicutes; 0.3\% Fusobacteria; 0.3\% Gemmatimonadetes; $0.3 \%$ Planctomycetes; $36.9 \%$ Proteobacteria; $0.3 \%$ Spirochaetes; 0.3 Thermotogae; and $0.3 \%$ could not be grouped to any phylum (Figure 1). In both the treatments, most of the sequences observed belonged to the Bacteria domain. A low percentage of individuals of Archaea domain were detected, even though the oligonucleotide used was specific for the Bacteria domain (Table 2). 

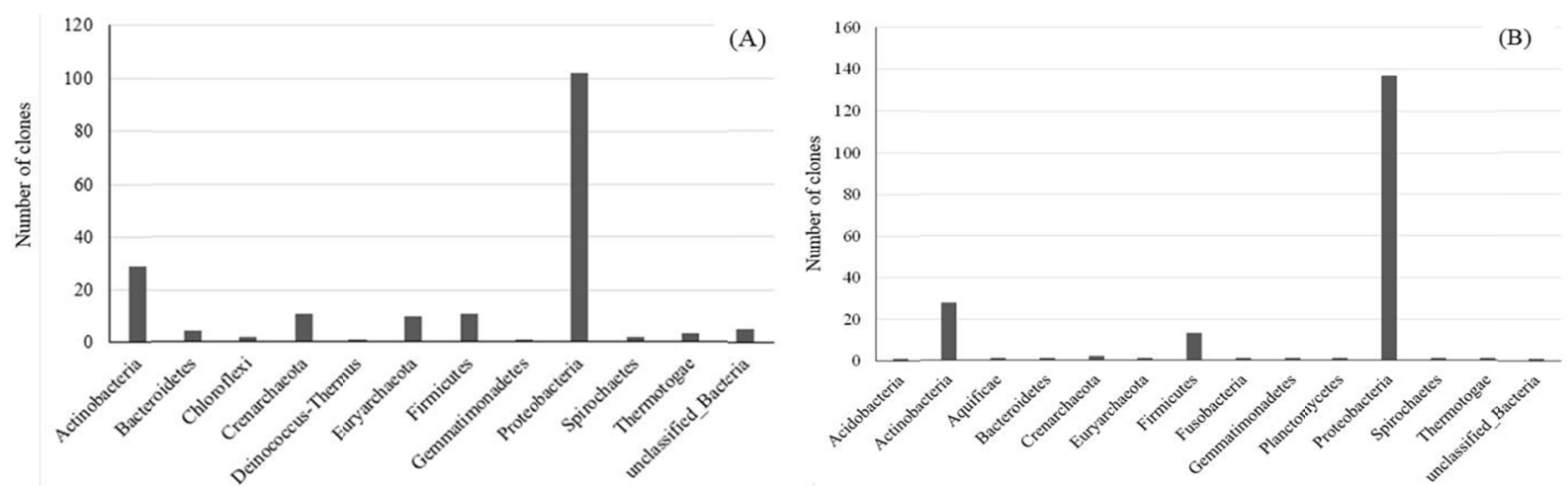

Figure 1. Clones obtained from partial sequences of the gene 16S rRNA from the soil with cultivation of $B t(\mathrm{~A})$ or non- $B t$ (B) cotton (150 D.A.S.)

Table 2. Distribution of the sequences of the $16 \mathrm{~S}$ rRNA clones observed in the soils cultivated with $B t$ or non- $B t$ cotton

\begin{tabular}{|c|c|c|c|c|}
\hline \multirow{2}{*}{ Phylum } & \multicolumn{4}{|c|}{ Number of observed clones } \\
\hline & $B t$ & $\%$ & Non- $B t$ & $\%$ \\
\hline \multicolumn{5}{|l|}{ Bacteria domain } \\
\hline Acidobacteria & 0 & 0.0 & 1 & 0.3 \\
\hline Actinobacteria & 29 & 7.8 & 28 & 7.5 \\
\hline Aquificae & 0 & 0.0 & 1 & 0.3 \\
\hline Bacteroidetes & 4 & 1.1 & 1 & 0.3 \\
\hline Chloroflexi & 2 & 0.5 & 0 & 0.0 \\
\hline Deinococcus-Thermus & 1 & 0.3 & 0 & 0.0 \\
\hline Firmicutes & 11 & 3.0 & 13 & 3.5 \\
\hline Fusobacteria & 0 & 0.0 & 1 & 0.3 \\
\hline Gemmatimonadetes & 1 & 0.3 & 1 & 0.3 \\
\hline Planctomycetes & 0 & 0.0 & 1 & 0.3 \\
\hline Proteobacteria & 102 & 27.5 & 137 & 36.9 \\
\hline Spirochaetes & 2 & 0.5 & 1 & 0.3 \\
\hline Thermotogae & 3 & 0.8 & 1 & 0.3 \\
\hline Unclassified Bacteria & 5 & 1.3 & 1 & 0.3 \\
\hline \multicolumn{5}{|l|}{ Archaea domain } \\
\hline Crenarchaeota & 11 & 3.0 & 2 & 0.5 \\
\hline Euryarchaeota & 10 & 2.7 & 1 & 0.3 \\
\hline Total & 181 & 48.8 & 190 & 51.2 \\
\hline
\end{tabular}

Note. Percentages referring to the amount of the phyla detected within the cultivation comparing through normalized data, obtained by comparing with RDP.

Analyses of the phylogenetic trees were done to determine which group the unidentified organisms belonged to and to identify the most abundant groups observed in each sample of the soil studied. Thus, an analysis of the major groups found in the soils with the cultivation of $B t$ or non- $B t$ cotton was performed (Figures 2 and 3 ). 


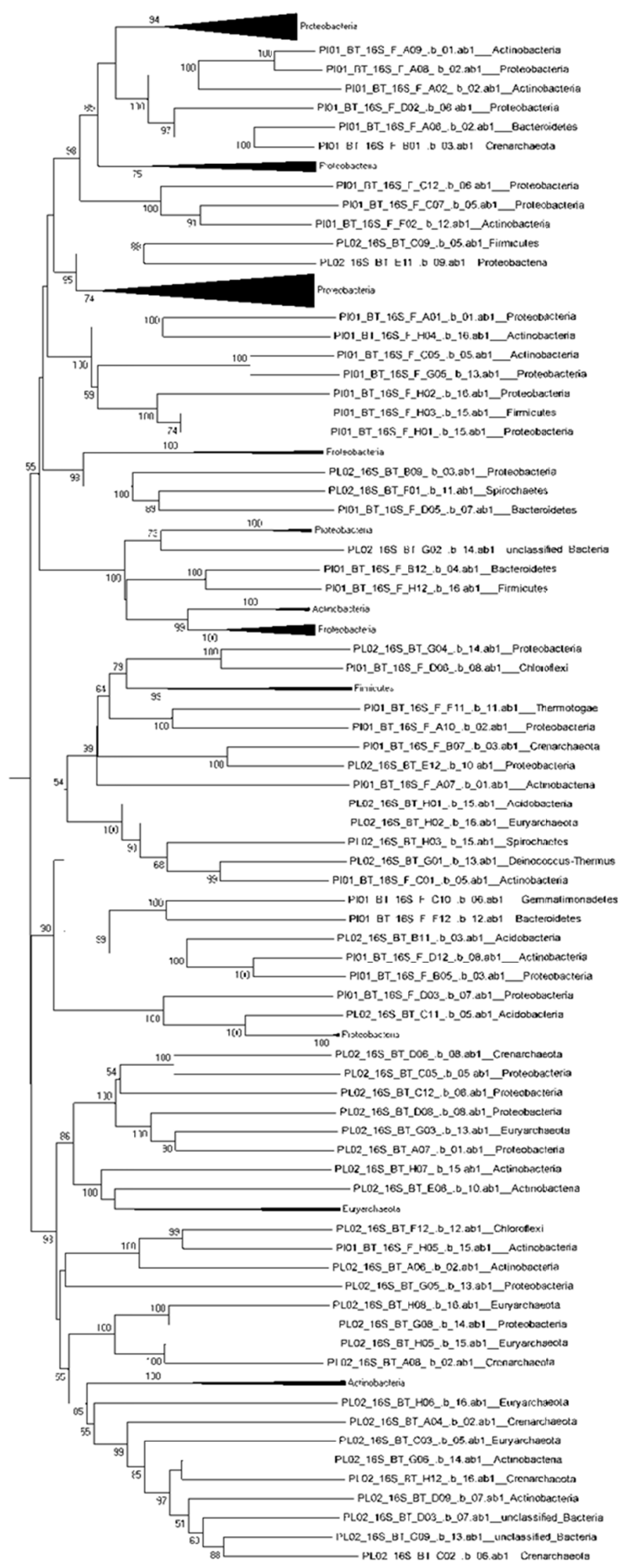

$\longmapsto$

Figure 2. Phylogenetic tree illustrating the phylogenetic relationship between sequences obtained by the method of partial sequencing of the gene $16 \mathrm{~S}$ rRNA from the soil cultivated with $B t$ cotton 


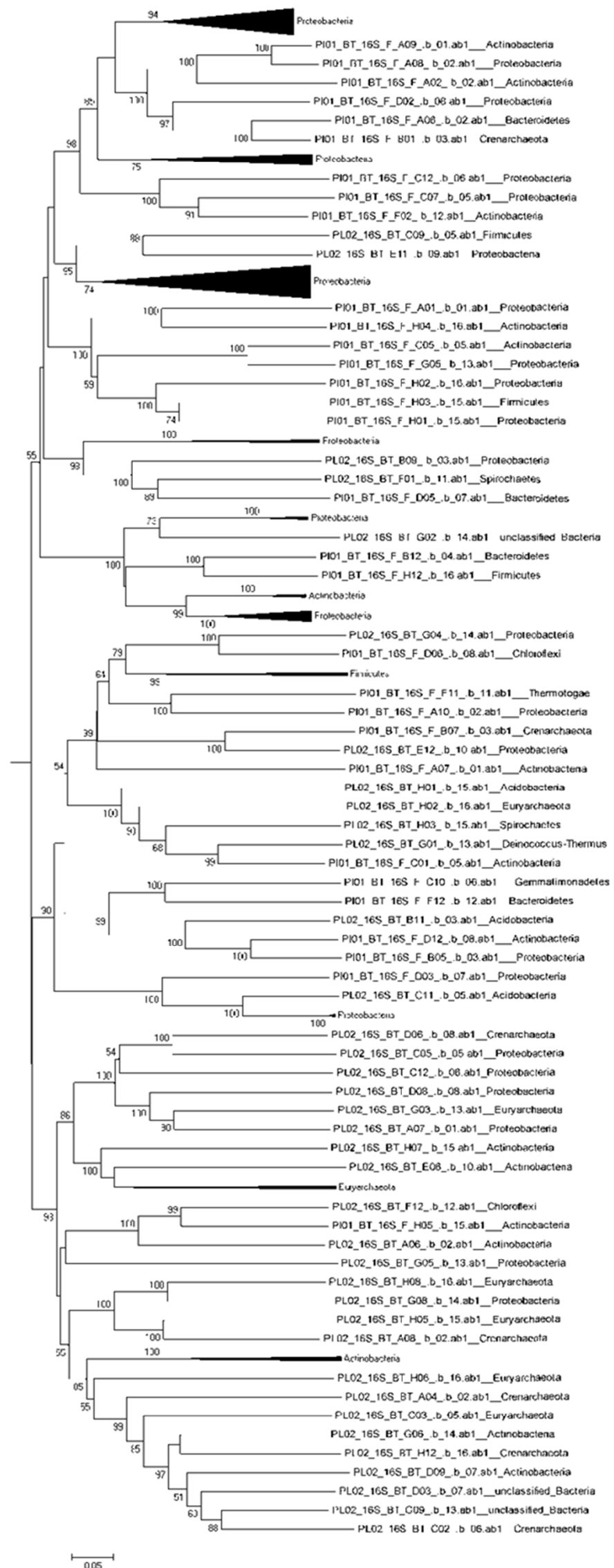

Figure 3. Phylogenetic tree illustrating the phylogenetic relationship between sequences obtained by the method of partial sequencing of the gene $16 \mathrm{~S}$ rRNA from the soil cultivated with non-Bt cotton 
Among the phyla that were observed only in the soil cultivated with non-Bt cotton are Acidobacteria, Aquificae, and Fusobacteria, showing 1\% occurrence (Table 2). The phylum Acidobacteria serves as an indicator of the soil nutritional condition with low growing potential (Smit, Leeflang, \& Gommans, 2001). This phylum is generally abundant in most of the soils (Kuske, Barns, \& Busch, 1997; Felske, Wolterink, Van Lis, De Vos, \& Akkermans, 2000; Nogales et al., 2001); however, in the current work it was recorded only in the non-Bt library, where only one clone was found, which corroborates the findings of Kishimoto and Tano (1987) and Sait, Hugenholtz, and Janssen (2002). The phylum Aquificae constitutes the oldest evolutionary line in the Bacteria domain, encompassing gran-negative autotrophic organisms; such organisms are strictly thermophilic with optimum growth generally occurring above $65^{\circ} \mathrm{C}$ (Deckert et al., 1998; Reysenbach et al., 2001; Huber \& Eder, 2006). In terms of metabolism, most of the species of Aquificae phylum are hydrogen-oxidants and use hydrogen as the electron donor and oxygen as the electron acceptor (Reysenbach et al., 2001; Huber \& Eder, 2006). Alternatively, thiosulfate or sulfur may also be utilized as energy sources owing to their thermostability. Many of the enzymes participating in their metabolism are of interest for industrial and biotechnological applications (Huber \& Stetter, 1998; Van den Burg, 2003).

The presence of Planctomycetes phylum was also reported only in the non- $B t$ soil, with an occurrence of $0.3 \%$ (Table 2). This phylum is constituted of aerobic organisms, which reproduce by budding, and is one of the few bacterial groups that do not possess peptidoglycan in their cell wall. Although there are several strains of this phylum in culture collections, according to Griepenburg et al. (1999), this phylum was rarely found in soil samples. This justifies its occurrence in only one of the areas studied in this work.

Apart from these, other phyla were recorded only in the soil cultivated with Bt cotton, such as Chloroflexi, which displayed an occurrence of $0.5 \%$ (Table 2). This phylum is constituted of heterotrophic, aerobic, and filamentous organisms and, despite being found in soils, little is known about the role they play. They possess a high diversity of phenotypes even among the few isolates that have been cultured (Rappé \& Giovannoni, 2003).

Deinococcus-Thermus displayed an occurrence of $0.3 \%$, with presence only in the soil sown with $B t$ cotton (Table 2). This phylum is well known due to its resistance to the UV rays, desiccation, ionizing radiation, hydrogen peroxide, and other agents that damage the DNA. Such resistance is possible due to a high efficiency in their DNA repair system. There is a great interest in this phylum regarding their application in bioremediation of sites contaminated with radiation and toxic chemical products, and due to their production of a series of thermostable enzymes of biotechnological importance, such as the Taq polymerase (Minton, 1994; Battista, 1997; Ferreira et al., 1997; Brim et al., 2000).

Concerning the phyla found in both the treatments, namely the soil cultivated with $B t$ or non-Bt cotton, the phylum Proteobacteria had the highest number of clones, followed by Actinobacteria and Firmicutes. The occurrence of Proteobacteria was $27.5 \%$ in $B t$ field and $36.9 \%$ in non-Bt field, Actinobacteria was $7.8 \%$ in $B t$ and $7.5 \%$ in non-Bt, and Firmicutes was $3.0 \%$ in $B t$ and $3.5 \%$ in non-Bt, respectively (Table 2). The following classes of Proteobacteria were revealed in the studied fields: Alphaproteobacteria, Betaproteobacteria, Deltaproteobacteria, Gammaproteobacteria, and Epsilonproteobacteria (Figure 4). This phylum is one of the largest and most varied among the phyla of culturable bacteria, showing a great morphological and metabolic diversity. Due to such characteristics, Proteobacteria occur in several environments (Hugenholtz et al., 1998; Dunbar et al., 1999; Smit et al., 2001), and this explains their appearance in both the soils, cultivated with $B t$ or non- $B t$ cotton. The result of our research corroborates Lee et al. (2011) study that analyzed the effect of genetically modified Zoysia grass (Zoysia japonica Steud.; Cyperales: Poaceae) on the soil bacterial community and observed that Proteobacteria was one of most abundant phyla among the assessed treatments. Other studies, such as by Janssen (2006), also reported this phylum as the most abundant, and Faoro et al. (2010) concluded that Proteobacteria was the most abundant bacteria phylum in soil samples of Atlantic forest. Moreover, in comparison with Acidobacteria, which is reported as one of the most abundant phyla in several investigations, phylum Proteobacteria is more stable and does not seem to differ in response to crop rotation, harvest, and type of cultivar. This may explain the low percentage of occurrence of Acidobacteria in the current research, highlighting that this phylum does not develop well in acid soils (Val-Moraes, Valarini, Ghini, Lemos, \& Carareto-Alves, 2009), a characteristic of the cultivated the area of our study. Smit et al. (2001) suggested that the ratio between the number of Proteobacteria and Acidobacteria serves as an indication of the nutritional condition of the soil, considering that Proteobacteria has a high growth potential, whereas Acidobacteria has a low growth potential. 


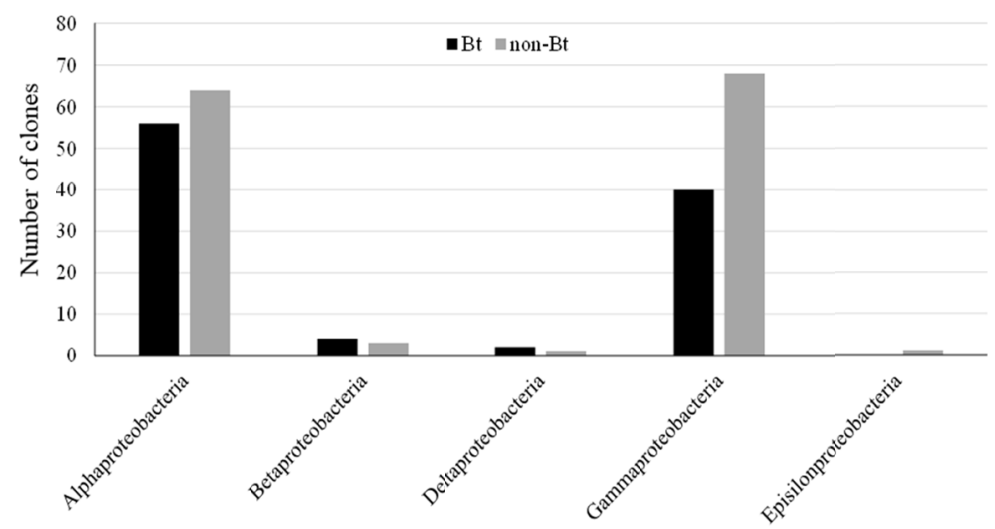

Figure 4. Clones belonging to Proteobacteria obtained from partial sequences of the gene 16S rRNA from the soils cultivated with $B t$ or non-Bt cotton

The phylum Actinobacteria had the second highest occurrence in both the soils cultivated with $B t$ or non-Bt cotton cultivars, with $7.8 \%$ in $B t$ and $7.5 \%$ in non- $B t$ field (Table 2). Actinomycetes are widely distributed in nature, inhabiting mainly in the soil. They possess important bioactive compounds of high commercial value (Oskay, Tamer, \& Azeri, 2004). This phylum belongs to a group, also known to be gram-negative bacteria with elevated $\mathrm{G}+\mathrm{C}$ content, whose individuals have DNA $\mathrm{G}+\mathrm{C}$ content superior to $50-55 \%$. The members of this group are prokaryotes with great morphological diversity that include cocci, regular or irregular rods, and branched hyphae. None of these bacteria produce true endospores, although many form asexual spores and some have complex life cycles. Their cell walls show considerable variation in their chemical composition, especially in regards to the peptidoglycan (Janssen, Yates, Grinton, Taylor, \& Sait, 2002). Actinobacteria is considered an important phylum, due to its characteristic of production of several antibiotics, and, thus, can control growth of many bacterial groups (Keller \& Zengler, 2004). This suggests that Actinobacteria may have inhibited the development of other phyla in our study.

The phyla Proteobacteria and Actinobacteria are related with the soil environment and, consequently, are less affected by alterations in the plants' metabolism and nutrient release in the rhizospheric environment (Gomes et al., 2001; Salles, Van Elsas, \& Van Veen, 2006; LeBlanc, Gonçalves, \& Mohn, 2008; Spain, Krumholz, \& Elshahed, 2009). Therefore, this is the best plausible hypothesis to explain the occurrence of both phyla in greater abundance in both the soils cultivated with $B t$ or non-Bt cotton.

Firmicutes was the third phylum with greater occurrence in both the soils cultivated with different cotton cultivars, occurring at $3.0 \%$ in $B t$ and $3.5 \%$ in non- $B t$ soils (Table 2). This phylum, also known as a group of gram-positive bacteria with low content of $\mathrm{G}+\mathrm{C}$, is constituted of organisms whose $\mathrm{G}+\mathrm{C}$ DNA content is lower than 50\% (Reichmann \& Gründling, 2011), with most of them being heterotrophic (Diaz et al., 2013). The mycoplasmas are also included in this group, although they do not possess a cell wall and hence react as gram-negatives in gram staining (Song, Wang, Shen, Pan, \& Huang, 2014). This group displays a considerable morphologic diversity, with cocci, linear rods, spirilos, and pleomorphic forms, such as the mycoplasmas belonging to this group (El Baidouri, Venditti, \& Humphries, 2017). Some members form endospores, such as Bacillus thuringiensis (Kailas et al., 2011), the bacterium from which the Cry1Ac gene was isolated, and later implanted into the transgenic cotton cultivar that was studied in our research.

Presence of Archaea domain was detected in this work, in both the soils, those cultivated with transgenic or conventional cotton. Overall, representatives of this domain have been isolated from extremophiles' habitats (Rampelotto, 2013) and generally have a chemoautotrophic metabolism (Bergauer, Sintes Van Bleijswijk, Witte, \& Herndl, 2013). The Archaea domain is divided into two phyla based on the rRNA sequences: Euryarchaeota and Crenarchaeota (Woese, Kandler, \& Wheelis, 1990).

In both the soils, we observed the existence of some microorganisms that were neither classified nor grouped to any bacterial phylum ( $1.3 \%$ in $B t$ cotton field and $0.3 \%$ in non- $B t$ field). These, according to Ward (2002) indicate a possibility of being new unculturable phyla belonging to the Bacteria domain.

Considering the indices of Shannon and Simpson (Table 3), it appears that these differences are not significant, because, overall, all data obtained in this research show that the cultivation of $B t$ cotton does not affect the quantity and diversity of soil microbial population. 
Table 3. Indexes of Shannon and Simpson of both cultivars expressed in percentages

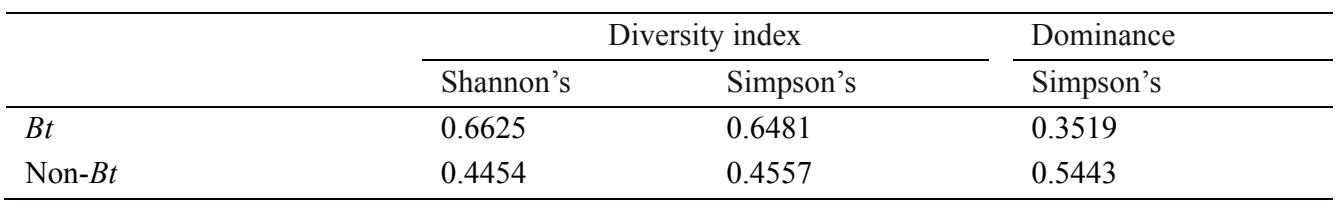

All parameters assessed in this investigation did not indicate any effect of GMPs on populations of soil bacteria. Both treatments had some phyla that were not reported in the other one. For instance, Acidobacteria, Aquificae, Fusobacteria, and Planctomycetes were reported only in the soil cultivated with non-Bt cotton, whilst Chloroflexi and Deinococcus-Thermus were found only in the soil cultivated with Bt cotton (Figure 1). Although these phyla were registered in only one of the two treatments, the representative number of each one of these phyla is not considered statistically significant, and thus, should not be attributed as an impacting or favoring factor for these species. In this sense, it is emphasized that the bacterial community in soils may also show fluctuations and successions over time (Jung, 2007). Thus, assessments of impact of transgenic crops on microorganisms may display variations that not always are associated with the cultivation of GMPs, but to environmental factors, such as temperature and humidity. Natural differences between samples were suggested as the main causes of variation in some of the earlier studies, rather than the effects of GMPs (Heuer, Kroppenstedt, Lottmann, Berg, \& Smalla, 2002; Blackwood \& Buyer, 2004; Fang, Kremer, Motavalli, \& Davis, 2005).

Widmer (2007), in a review on effects of transgenic crops on soil bacterial community, concluded that the environmental factors or type of cultivated plant species often have higher effects on the soil microbiological characteristics than the transgenic treatments, and the reported effects are restricted to the rhizosphere of the transgenic plants and remain only during the period in which they are present.

Corroborating the results obtained in our research, other studies on transgenic plants also did not detect significant effects of Bt proteins on the soil bacterial populations (Chiarini, Bevivino, Dalmastri, Nacamulli, \& Tabachioni, 1998; Min, Kremer, Motavalli, \& Davis, 2005). Schmalenberger and Tebbe (2002) did not find significant differences on the bacterial community between the soil cultivated with herbicide-resistant maize and its non-transgenic isoline, as studied using the technique of 16S rDNA PCR- SSCP (Single-strand conformation polymorphism).

Li et al. (2011) evaluated the impact of transgenic cotton resistant to insects (Cry1Ac) during three years of consecutive cultivation and found that the long-term cultivation of transgenic cotton did not show significant adverse effects on soil microorganisms. The study developed by Shen et al. (2006), did not report any significant effects of $B t$ cotton on the soil microbial diversity, and the study by Saxena and Stotzky (2001), did not record any alterations in the number of aerobic bacteria and fungi that could arise due to a possible negative effect of $\mathrm{cry} 1 \mathrm{Ab}$ protein from the maize root exudates, and, during the tissue decomposition. Results from such studies reinforce the results obtained in our research here, in which the $B t$ cotton caused no significant negative effect on the population of soil bacteria in field conditions, when compared with its isoline non-Bt cotton.

On the contrary, different results were found in other research studies. Donegan et al. (1995) observed that two cotton hybrids, which express the B. thuringiensis endotoxin, caused an increase in the number of total bacterial and fungal populations when compared to the other treatments, with also changes detected in the diversity of the bacterial community. Wei et al. (2006) studied the influence of the cultivation of transgenic papaya resistant to virus on the microbial population and registered significant increases in the number of colony-forming units (CFUs) of bacteria, actinomycetes, and soil fungi, compared to the soil cultivated with conventional papaya. Dunfield and Germida (2001) observed differences in the functional diversity and composition of the microbial community in the rhizosphere of a canola (B. napus L.) transgenic variety (tolerant to herbicide), when compared to the conventional variety. Nevertheless, contrasting findings have also been reported. For example, Rui et al. (2005) noted higher number of functional bacteria associated with roots of conventional cotton when compared to the rhizosphere of varieties of transgenic cotton (NuCOTN99 (Bt) and SGK321 (Bt + CpTI)).

Emphasizing these findings, some authors, such as Dunfield and Germida $(2003,2004)$ and $\mathrm{Hu}$ et al. (2009), affirmed that when there is occurrence of some type of GMP effect on soil microorganisms, such effect is considered temporary and transitory, because it disappears after removing the plants from the field.

In conclusion, our research suggests that there does not seem to be a negative influence of the $B t$ cotton cultivar on the quantity and diversity of the soil bacterial population. However, it is necessary to perform continuous and 
systematic monitoring to ascertain whether transgenic cultivars could damage the soil microbiota. Such monitoring needs to be conducted through utilization of different approaches once there is a range of $B t$ proteins available in the market, which may show different effects depending on the locality in which the cotton is grown. This research contributes towards revealing that the cultivation of $B t$ cotton does not seem to affect the soil bacterial population in a Brazilian savannah region, a result that is similar to that of most of the research conducted worldwide.

\section{References}

Battista, J. R. (1997). Against all odds: The survival strategies of Deinococcus radiodurans. Annual Review of Microbiology, 51, 203-224. https://doi.org/10.1146/annurev.micro.51.1.203

Benekos, K., Kissoudis, C., Nianiou-Obeidat, I., Labrou, N., Madesis, P., Kalamaki, M., ... Tsaftaris, A. (2010). Overexpression of a specific soybean GmGSTU4 isoenzyme improves diphenyl ether and chloroacetanilide herbicide tolerance of transgenic tobacco plants. Journal of Biotechnology, 150, 195-201. https://doi.org/ 10.1016/j.jbiotec.2010.07.011

Bergauer, K., Sintes, E., Van Bleijswijk, J., Witte, H., \& Herndl, G. J. (2013). Abundance and distribution of archaeal acetyl-CoA/propionyl-CoA carboxylase genes indicative for putatively chemoautotrophic Archaea in the tropical Atlantic's interior. FEMS Microbiology Ecology, 84, 461-473. https://doi.org/10.1111/ 1574-6941.12073

Blackwood, C. B., \& Buyer, J. S. (2004). Soil microbial communities associated with Bt and non-Bt corn in three soils. Journal of Environmental Quality, 33, 832-836. https://doi.org/10.2134/jeq2004.0832

Bommireddy, P. L., \& Leonard, B. R. (2008). Survivorship of Helicoverpa zea and Heliothis virescens on cotton plant structures expressing a Bacillus thuringiensis vegetative insecticidal protein. Journal of Economic Entomology, 101, 1244-1252. https://doi.org/10.1093/jee/101.4.1244

Brim, H., McFarlan, S. C., Fredrickson, J. K., Minton, K. W., Zhai, M., Wackett, L. P., \& Daly, M. J. (2000). Engineering Deinococcus radiodurans for metal remediation in radioactive mixed waste environments. Nature Biotechnology, 18, 85-90. https://doi.org/10.1038/71986

Cheeke, T. E., Darby, H., Rosenstiel, T. N., Bever, J. D., \& Cruzan, M. B. (2014). Effect of Bacillus thuringiensis $(B t)$ maize cultivation history on arbuscular mycorrhizal fungal colonization, spore abundance and diversity, and plant growth. Agriculture, Ecosystems \& Environment, 195, 29-35. https://doi.org/10.1016/j.agee. 2014.05.019

Chiarini, L., Bevivino, A., Dalmastri, C., Nacamulli, C., \& Tabachioni, S. (1998). Influence of plant development, cultivar and soil type on microbial colonization of maize roots. Applied Soil Ecology, 8, 11-18. https://doi.org/10.1016/S0929-1393(97)00071-1

Deckert, G., Warren, P. V., Gaasterland, T., Young, W. G., Lenox, A. L., Graham, D. E...Swanson, R. V. (1998). The complete genome of the hyperthermophilic bacterium Aquifex aeolicus. Nature, 392, 353-358. https://doi.org/10.1038/32831

Diaz, J. M., Hansel, C. M., Voelker, B. M., Mendes, C. M., Andeer, P. F., \& Zhang, T. (2013). Widespread production of extracellular superoxide by heterotrophic bacteria. Science, 1237331. https://doi.org/10.1126/science.1237331

Donegan, K. K., Palm, C. J., Fieland, V. J., Porteus, L. A., Ganio, L. M., Schaller, D. L., Bucao, L. Q., \& Seidler, R. J. (1995). Changes in levels, species and DNA fingerprints of soil microorganisms associated with cotton expressing the Bacillus thuringiensis var. kurstaki endotoxin. Applied Soil Ecology, 2, 111-124. https://doi.org/10.1016/0929-1393(94)00043-7

Dunbar, J., Takala, S., Barns, S. M., Davis, J. A., \& Kuske, C. R. (1999). Levels of bacterial community diversity in four arid soils compared by cultivation and 16S rRNA gene cloning. Applied and Environmental Microbiology, 65, 1662-1669.

Dunfield, K. E., \& Germida J. J. (2004). Impact of genetically modified crops on soil- and plant-associated microbial communities. Journal of Environmental Quality, 33, 806-815. https:// doi:10.2134/jeq2004.0806

Dunfield, K. E., \& Germida, J. J. (2001). Diversity of bacterial communities in the rhizosphere and root interior of field-grown genetically modified Brassica napus. FEMS Microbiology Ecology, 38, 1-9. https://doi.org/ 10.1111/j.1574-6941.2001.tb00876.x 
Dunfield, K. E., \& Germida, J. J. (2003). Seasonal changes in the rhizosphere microbial communities associated with field-grown genetically modified canola (Brassica napus). Applied and Environmental Microbiology, 69, 7310-7318. https://doi.org/10.1128/AEM.69.12.7310-7318.2003

El Baidouri, F., Venditti, C., \& Humphries, S. (2017). Independent evolution of shape and motility allows evolutionary flexibility in Firmicutes bacteria. Nature Ecology and Evolution, 1, 0009. https://doi.org/ 10.1038/s41559-016-0009

Embrapa. (2001). Algodão: Tecnologia de produção. Dourados: Embrapa Algodão/Embrapa Agropecuária Oeste.

Embrapa. (2006). Sistema Brasileiro de Classificação de Solos. Rio de Janeiro: Embrapa (Centro Nacional de Pesquisa de Solos).

Fang, M., Kremer, R. J., Motavalli, P. P., \& Davis, G. (2005). Bacterial diversity in rhizospheres of nontransgenic and transgenic corn. Applied and Environmental Microbiology, 41, 4132-4136. https://doi.org/10.1128/AEM.71.7.4132-4136.2005

Faoro, H., Alves, A. C., Souza, E. M., Rigo, L. U., Cruz, L. M., Al-Janabi, S. M., ... Pedrosa, F. O. (2010). Influence of soil characteristics on the diversity of bacteria in the southern Brazilian Atlantic forest. Applied and Environmental Microbiology, 76, 4744-4749. https://doi.org/10.1128/AEM.03025-09

Felske, A., Wolterink, A., Van Lis, R., De Vos, W. M., \& Akkermans, A. D. (2000). Response of a soil bacterial community to grassland succession as monitored by $16 \mathrm{~S}$ rRNA levels of the predominant ribotypes. Applied and Environmental Microbiology, 66, 3998-4003. https://doi.org/10.1128/AEM.66.9.3998-4003.2000

Ferreira, A. C., Nobre, M. F., Rainey, F. A., Silva, M. T., Wait, R., Burghardt, J., ... Costa, M. S. (1997). Deinococcus geothermalis sp. nov. and Deinococcus murrayi sp. nov., two extremely radiation-resistant and slightly thermophilic species from hot springs. International Journal of Systematic and Evolutionary Microbiology, 47, 939-947. https://doi.org/10.1099/00207713-47-4-939

Fietz, C. R., \& Fisch, G. F. (2008). O clima da região de Dourados, MS. Dourados: Embrapa Agropecuária Oeste-Documentos.

Fischhoff, D. A., Bowdish, K. S., Perlak, F. J., Marrone, P. G., McCormick, S. M., Niedermeyer, J. G., ... Fraley, R. T. (1987). Insect tolerant transgenic tomato plants. Nature Biotechnology, 5, 807-813. https://doi.org/ $10.1038 / \mathrm{nbt} 0887-807$

Flores, S., Saxena, D., \& Stotzky, G. (2005). Transgenic Bt plants decompose less in soil than non-Bt plants. Soil Biology and Biochemistry, 37, 1073-1082. https://doi.org/10.1016/j.soilbio.2004.11.006

Gomes, N. C. M., Heuer, H., Schönfeld, J., Costa, R., Medonça-Hagler, L., \& Smalla, K. (2001). Bacterial diversity of the rhizosphere of maize (Zea mays) grown in tropical soil studied by temperature gradient gel electrophoresis. Plant and Soil, 232, 167-180. https://doi.org/10.1023/A:1010350406708

Gordon, D., Abajian, C., \& Green, P. (1998). Consed: A graphical tool for sequence finishing. Genome Research, 8, 195-202. https://doi.org/10.1101/gr.8.3.195

Griepenburg, U., Ward-Rainey, N., Mohamed, S., Schlesner, H., Marxsen, H., Rainey, F. A., ... Auling, G. (1999). Phylogenetic diversity, polyamine pattern and DNA base composition of members of the order Planctomycetales. International Journal of Systematic and Evolutionary Microbiology, 49, 689-696. https://doi.org/10.1099/00207713-49-2-689

Guerrante, R. D. S. (2003). Potenciais riscos e benefícios da tecnologia dos OGMs. In R. D. S. Guerrante (Ed.), Transgênicos: Uma visão estratégica (pp. 27-46). Rio de Janeiro: Interciência.

Heuer, H., Kroppenstedt, R. M., Lottmann, J., Berg, G., \& Smalla, K. (2002). Effects of T4 lysozyme release from transgenic potato roots on bacterial rhizosphere communities are negligible relative to natural factors. Applied and Environmental Microbiology, 68, 1325-1335. https://doi.org/10.1128/AEM.68.3.1325-1335. 2002

Hu, H. Y., Liu, X. X., Zhao, Z. W., Sun, J. G., Zhang, Q. W., Liu, X. Z., \& Yu, Y. (2009). Effects of repeated cultivation of transgenic Bt cotton on functional bacterial populations in rhizosphere soil. World Journal of Microbiology and Biotechnology, 25, 357-366. https://doi.org/10.1007/s11274-008-9899-8

Huber, H., \& Stetter, K. O. (1998). Hyperthermophiles and their possible potential in biotechnology. Journal of Biotechnology, 64, 39-52. https://doi.org/10.1016/S0168-1656(98)00102-3 
Huber, R., \& Eder, W. (2006). Aquificales. In M. Dworkin, S. Falkow, E. Rosenberg, K. Schleifer, \& E. Stackebrandt (Eds.), The Prokaryotes: An evolving electronic resource for the microbiological community (pp. 925-938). New York: Springer. https://doi.org/10.1007/0-387-30747-8_39

Hugenholtz, P., Pitulle, K. L., \& Pace, N. R. (1998). Novel division level bacterial diversity in a Yellowstone hot spring. Journal of Bacteriology, 180, 366-76.

Icoz, I., Saxena, D., Andow, D., Zwahlen, C., \& Stotzky, G. (2008). Microbial populations and enzyme activities in soil in situ under transgenic corn expressing cry proteins from Bacillus thuringiensis. Journal of Environmental Quality, 37, 647-662. https://doi.org/10.2134/jeq2007.0352

Janssen, P. H. (2006). Identifying the dominant soil bacterial taxa in libraries of 16S rRNA and 16S rRNA genes. Applied and Environmental Microbiology, 72, 1719-1728. https://doi.org/10.1128/AEM.72.3.1719-1728.2006

Janssen, P. H., Yates, P. S., Grinton, B. E., Taylor, P. M., \& Sait, M. (2002). Improved culturability of soil bacteria and isolation in pure culture of novel members of the divisions Acidobacteria, Actinobacteria, Proteobacteria, and Verrucomicrobia. Applied and Environmental Microbiology, 68, 2391-2396. https://doi.org/10.1128/AEM.68.5.2391-2396.2002

Jung, S. (2007). Study on the effects of genetically modified Brassica rapa subsp. pekinensis on the rhizosphere microbiota (Unpublished master's thesis, Chungnam National University, Daejeon, Republic of Korea).

Kailas, L., Terry, C., Abbott, N., Taylor, R., Mullin, N., Tzokov, S. B... \& Bullough, P. A. (2011). Surface architecture of endospores of the Bacillus cereus/anthracis/thuringiensis family at the subnanometer scale. Proceedings of the National Academy of Sciences of the United States of America, 108, 16014-16019. https://doi.org/10.1073/pnas.1109419108

Keller, M., \& Zengler, K. (2004). Tapping into microbial diversity. Nature Reviews Microbiology, 02, 141-150. https://doi.org/10.1038/nrmicro819

Kishimoto, N, \& Tano, T. (1987). Acidophilic heterotrophic bacteria isolated from acidic mine drainage, sewage, and soils. The Journal of General and Applied Microbiology, 33, 11-25. https://doi.org/10.2323/jgam.33.11

Kozdrój, J., \& Van Elsas, J. D. (2001). Structural diversity of microorganisms in chemically perturbed soil assessed by molecular and cytochemical approaches. Journal of Microbiological Methods, 43, 197-212. https://doi.org/10.1016/S0167-7012(00)00197-4

Kuske, C. R., Barns, S. M., \& Busch, J. D. (1997). Diverse uncultivated bacterial groups from soils of the arid southwestern United States that are present in many geographic regions. Applied and Environmental Microbiology, 63, 3614-3621.

Leblanc, J. C., Gonçalves, E. R., \& Mohn, W. W. (2008). Global response to desiccation stress in the soil actinomycete Rhodococcus jostii RHA1. Applied and Environmental Microbiology, 74, 2627-2636. https://doi.org/10.1128/AEM.02711-07

Lee, Y. E., Yang, S. H., Bae, T. W., Kang, H.G., Lim, P. O., \& Lee, H. Y. (2011). Effects of field-grown genetically modified Zoysia grass on bacterial community structure. Journal of Microbiology and Biotechnology, 21, 333-340. https://doi.org/10.4014/jmb.1010.10004

Li, X., Liu, B., Cui, J., Liu, D., Ding, S., Gilna, B., ... Han, Z. (2011). No evidence of persistent effects of continuously planted transgenic insect-resistant cotton on soil microorganisms. Plant and Soil, 339, 247-257. https://doi.org/10.1007/s11104-010-0572-2

Lövei, G. L., Andow, D. A., \& Arpaia, S. (2009). Transgenic insecticidal crops and natural enemies: A detailed review of laboratory studies. Environmental Entomology, 38, 293-306. https://doi.org/10.1603/022.038. 0201

Martins, E. S., Aguiar, R. W. D. S., Martins, N. F., Melatti, V. M., Falcão, R., Gomes, A. C. M. M., ... Monnerat, R. G. (2008). Recombinant Crylla protein is highly toxic to cotton boll weevil (Anthonomus grandis Boheman) and fall armyworm (Spodoptera frugiperda). Journal of Applied Microbiology, 104, 1363-1371. https://doi.org/10.1111/j.1365-2672.2007.03665.x

Min, F., Kremer, R. J., Motavalli, P. P., \& Davis, G. (2005). Bacterial diversity in rhizospheres of nontransgenic and transgenic corn. Applied and Environmental Microbiology, 71, 4132-4136. https://doi.org/10.1128/ AEM.71.7.4132-4136.2005

Minton, K. W. (1994). DNA repair in the extremely radioresistant bacterium Deinococcus radiodurans. Molecular Microbiology, 13, 9-15. https://doi.org/10.1111/j.1365-2958.1994.tb00397.x 
Monnerat, R., \& Bravo, A. (2000). Proteinas bioinseticidas produzidas pela bactéria Bacillus thuringiensis: modo de ação e resistência. In I. S. Melo, \& J. L. Azevedo (Eds.), Controle biológico (pp. 163-200). Jaguariúna: Embrapa Meio Ambiente.

Neder, R. N. (1992). Microbiologia: Manual de laboratório. São Paulo: Nobel.

Nogales, B., Moore, E. R. B., Llobet-Brossa, E., Rossello-Mora, R., Amann. R, \& Timmis, K. N. (2001). Combined use of $16 \mathrm{~S}$ ribosomal DNA and 16S rRNA to study the bacterial community of polychlorinated biphenyl-polluted soil. Applied and Environmental Microbiology, 67, 1874-1884. https://doi.org/10.1128/ AEM.67.4.1874-1884.2001

O’Donnell, A. G., \& Göres, H. E. (1999). 16S rDNA methods in soil microbiology. Current Opinion in Biotechnology, 10, 225-229. https://doi.org/10.1016/S0958-1669(99)80039-1

Olsen, R. A., \& Bakken, L. R. (1987). Viability of soil bacteria: Optimization of plate counting technique and comparison between total counts and plate counts within different size groups. Microbial Ecology, 13, 59-74. https://doi.org/10.1007/BF02014963

Oskay, M., Tamer, A. U., \& Azeri, C. (2004). Antibacterial activities of some actinomycetes isolated from farming soils of Turkey. African Journal of Biotechnology, 3, 441-446.

Pereira, J. C., Neves, M. C. P., \& Drozdowicz, A. (1996). Quantificações das populações de bactérias em geral, de bactérias resistentes a antibióticos e de actinomicetos em solos. Seropédica: Embrapa-CNPAB.

Pereira, R. M., Silveira, E. L., Scaquitto, D. C., Pedrinho, E. A. N., Val-Moraes, S. P., Wickert, E., ... Lemos, E. G. M. (2006). Molecular characterization of bacterial populations of different soils. Brazilian Journal of Microbiology, 4, 439-447. https://doi.org/10.1590/S1517-8382200600 0400007

Peters, S., Koschinsky, S., Schwieger, F., \& Tebbe, C. C. (2000). Succession of microbial communities during hot composting as detected by PCR-single-strand-conformation polymorphism-based genetics profiles of small-subunit rRNA genes. Applied and Environmental Microbiology, 66, 930-936. https://oi.org/10.1128/ AEM.66.3.930-936.2000

Pinto, L. M. N., \& Fiuza, L. M. (2008). Genes cry de Bacillus thuringiensis aplicados na engenharia genética de plantas, conferindo resistência a insetos-praga. Neotropical Biology and Conservation, 3, 159-168. https://doi.org/10.4013/nbc.20083.07

Rampelotto, P. H. (2013). Extremophiles and extreme environments. Life, 3, 482-485. https://doi.org/10.3390/ life 3030482

Ranjard, L., Poly, F., Combrisson, J., Richaume, A., Gourbière, F., Thioulouse, J., \& Nazaret, S. (2000). Heterogeneous cell density and genetic structure of bacterial pools associated with various soil microenvironments as determined by enumeration and DNA fingerprinting approach (RISA). Microbial Ecology, 39, 263-72. https://doi.org/10.1007/s002480000032

Rappé, M. S., \& Giovannoni, S. J. (2003). The uncultured microbial majority. Annual Review of Microbiology, 57, 369-394. https://doi.org/10.1146/annurev.micro.57.030502.090759

Reichmann, N. T., \& Gründling, A. (2011). Location, synthesis and function of glycolipids and polyglycerolphosphate lipoteichoic acid in Gram-positive bacteria of the phylum Firmicutes. FEMS Microbiology Letters, 319, 97-105. https://doi.org/10.1111/j.1574-6968.2011.02260.x

Reysenbach, A. L., Huber, R., Stetter, K. O., Ishii, M., Kawasumi, T., Igarashi, Y., Eder, W., L’Haridon, S., \& Jeanthon, C. (2001). Phylum BI. Aquificae phy. nov. In D. R. Boone, R. W. Castenholz, \& G. M. Garrity (Eds.), Bergey's Manual of Systematic Bacteriology (pp. 359-367). New York: Springer. https://doi.org/ 10.1007/978-0-387-21609-6 19

Rui, Y. K., Yi, G. X., Zhao, J., Wang, B. M., Li, Z. H., \& Zhai, Z. X. (2005). Changes of Bt toxin in the rhizosphere of transgenic Bt cotton and its influence on soil functional bacteria. World Journal of Microbiology and Biotechnology, 21, 1279-1284. https://doi.org/10.1007/s11274-005-2303-z

Sait, M., Hugenholtz, P., \& Janssen, P. H. (2002). Cultivation of globally distributed soil bacteria from phylogenetic lineages previously only detected in cultivation-independent surveys. Environmental Microbiology, 4, 654-666. https://doi.org/10.1046/j.1462-2920.2002.00352.x

Saitou, N., \& Nei, M. (1987). The neighbor-joining method: A new method for constructing phylogenetic trees. Molecular Biology and Evolution, 4, 406-425. https://doi.org/10.1093/oxfordjournals.molbev.a040454 
Salles, J. F., Van Elsas, J. D., \& Van Veen, J. A. (2006). Effect of agricultural management regime on Burkholderia community structure in soil. Microbial Ecology, 52, 267-279. https://doi.org/10.1007/s00248 -006-9048-6

Sarowar, S., Kim, Y. J., Kim, K. D., Hwang, B. K., Ok, S. H., \& Shin, J. S. (2009). Overexpression of lipid transfer protein (LTP) genes enhances resistance to plant pathogens and LTP functions in long-distance systemic signaling in tobacco. Plant Cell Reports, 28, 419-427. https://doi.org/10.1007/s00299008-0653-3

Saxena, D., \& Stotzky, G. (2001). Bacillus thuringiensis (Bt) toxin released from root exudates and biomass of Bt corn has no apparent effect on earthworms, nematodes, protozoa, bacteria, and fungi in soil. Soil Biology and Biochemistry, 33, 1225-1230. https://doi.org/10.1016/S0038-0717(01)00027-X

Schmalenberger, A., \& Tebbe, C. C. (2002). Bacterial community composition in the rhizosphere of a transgenic, herbicide-resistant maize (Zea mays) and comparison to its non-transgenic cultivar Bosphore. FEMS Microbiology Ecology, 40, 29-37. https://doi.org/10.1111/j.1574-6941.2002.tb00933.x

Shen, R. F., Cai, H., Gong, \& W. H. (2006). Transgenic Bt cotton has no apparent effect on enzymatic activities or functional diversity of microbial communities in rhizosphere soil. Plant and Soil, 285, 149-159. https://doi.org/10.1007/s11104-006-9000-z

Silveira, E. L., Pereira, R. M., Scaquitto, D. C., Pedrinho, E. A. N., Val-Moraes, S. P., Wickert, E., ... E. G. M. (2006). Bacterial diversity of soil under eucalyptus assessed by $16 \mathrm{~S}$ rDNA sequencing analysis. Pesquisa Agropecuária Brasileira, 41, 1507-1516. https://doi.org/10.1590/S0100-204X2006001000008

Smit, E., Leeflang, P., \& Gommans, S. (2001). Diversity and seasonal fluctuations of the dominant members of the bacterial soil community in a wheat field as determined by cultivation and molecular methods. Applied and Environmental Microbiology, 67, 2284-2291. http://dx.doi.org/10.1128/AEM.67.5.2284-2291.2001

Song, T. J., Wang, Y., Shen, J. G., Pan, J. P., \& Huang, J. (2014). Genomic comparisons between paired bacterial strains with strong and weak GC skews. Journal of Basic Microbiology, 54, 111-119. https://doi.org/ 10.1002/jobm.201200252

Sorheim, R., Torsvik, V. L., \& Goksoyr, J. (1989). Phenotypical divergences between populations of soil bacteria isolated on different media. Microbial Ecology, 17, 181-192. https://doi.org/10.1007/BF02011852

Spain, A. M., Krumholz, L. R., \& Elshahed, M. S. (2009). Abundance, composition, diversity and novelty of soil Proteobacteria. The ISME Journal, 3, 992-1000. https://doi.org/10.1038/ismej.2009.43

Tabashnik, B. E., Brévault, T., \& Carrière, Y. (2013). Insect resistance to Bt crops: Lessons from the first billion acres. Nature Biotechnology, 31, 510-521. https://doi.org/10.1038/nbt.2597

Thorton, H. G. (1922). On the development of a standardized agar medium for counting soil bacteria with special regard to the repression of spreading colonies. Annals of Applied Biology, 9, 241-274. https://doi.org/ 10.1111/j.1744-7348.1922.tb05958.x

Val-Moraes, S. P., Valarini, M. J., Ghini, R., Lemos, E. G. M., \& Carareto-Alves, L. M. (2009). Diversidade de bactérias de solo sob vegetação natural e cultivo de hortaliças. Revista Ciência Agronônica, 40, 7-16.

Van Den Burg, B. (2003). Extremophiles as a source for novel enzymes. Current Opinion in Microbiology, 6, 213-218. https://doi.org/10.1016/S1369-5274(03)00060-2

Ward, B. B. (2002). How many species of prokaryotes are there? Proceedings of the National Academy of Sciences of the United States of America, 99, 10234-10236. https://doi.org/10.1073/pnas.162359199

Wei, X. D., Zou, H. L., Chu, L. M., Liao, B., \& Lan, C. Y. (2006). Field released transgenic papaya affects microbial communities and enzyme activities in soil. Plant and Soil, 285, 347-358. https://doi.org/ 10.1007/s11104-006-9020-8

Weisburg, W. G., Barns, S. M., Pelletier, D. A., \& Lane, D. J. (1991). 16S ribosomal DNA amplification for phylogenetic study. Journal of Bacteriology, 173, 697-703. 10.1128/jb.173.2.697-703.1991

Widmer, F. (2007). Assessing effects of transgenic crops on soil microbial communities. In A. Fiechter, \& C. Sautter (Eds.), Green Gene Technology (pp. 207-234). Berlin: Springer. https://doi.org/10.1007/10 2007_047

Woese, C. R., Kandler, O., \& Wheelis, M. L. (1990). Towards a natural system of organisms: Proposal for the domains Archaea, Bacteria, and Eucarya. Proceedings of the National Academy of Sciences of the United 
States of America, 87, 4576-4579. https://doi.org/10.1073/pnas.87.12.4576

Wu, K. M., Lu, Y. H., Feng, H. Q., Jiang, Y. Y., \& Zhao, J. Z. (2008). Suppression of cotton bollworm in multiple crops in China in areas with Bt toxin-containing cotton. Science, 321, 1676-1678. https://doi.org/ 10.1126/science. 1160550

Zhu, J. Q., Liu, S., Ma, Y., Zhang, J. Q., Qi, H. S., Wei, Z. J., ... Li, S. (2012). Improvement of pest resistance in transgenic tobacco plants expressing dsRNA of an insect-associated gene EcR. PloS One, 7, e38572. https://doi.org/10.1371/journal.pone.0038572

\section{Appendix A}

Physical and chemical characterization of soils cultivated with Bt or non-Bt cotton at 150 D.A.S.

\begin{tabular}{|c|c|c|}
\hline \multirow{2}{*}{ Parameters } & \multicolumn{2}{|c|}{ Type of cultivated plant } \\
\hline & $B t$ & Non- $B t$ \\
\hline Clay & 76.9 & 78.5 \\
\hline Sand & 11.4 & 12.5 \\
\hline Silt & 11.7 & 9.0 \\
\hline $\mathrm{K}$ & 7.6 & 10.7 \\
\hline $\mathrm{P}$ & 20.4 & 24.6 \\
\hline $\mathrm{Al}$ & 1.6 & 2.9 \\
\hline $\mathrm{Ca}$ & 5.2 & 5.8 \\
\hline $\mathrm{Mg}$ & 2.3 & 2.7 \\
\hline $\mathrm{H}+\mathrm{Al}$ & 4.6 & 5.4 \\
\hline $\mathrm{V} \%$ & 64.5 & 63.6 \\
\hline $\mathrm{T}$ & 128.2 & 149.5 \\
\hline S.B. & 82.3 & 95.7 \\
\hline $\mathrm{C} \%$ & 1.2 & 1.0 \\
\hline M.O. & 20.9 & 17.2 \\
\hline $\mathrm{pH} \mathrm{H} \mathrm{H}_{2} \mathrm{O}$ & 6.1 & 6.0 \\
\hline $\mathrm{pH} \mathrm{CaCl}{ }_{2}$ & 5.0 & 5.2 \\
\hline pH SMP & 6.2 & 6.0 \\
\hline $\mathrm{Cu}$ & 9.2 & 6.5 \\
\hline $\mathrm{Zn}$ & 2.4 & 1.2 \\
\hline $\mathrm{Fe}$ & 51.3 & 22.5 \\
\hline $\mathrm{Mn}$ & 71.5 & 55.2 \\
\hline
\end{tabular}

Note. $\mathrm{P}, \mathrm{Cu}, \mathrm{Fe}, \mathrm{Zn}$ and $\mathrm{Mn}: \mathrm{mg} / \mathrm{dm}^{3}$; $\mathrm{Ca}, \mathrm{Mg}$ and $\mathrm{H}+\mathrm{Al}: \mathrm{cmol} ; \mathrm{K}$ and $\mathrm{Al}: \mathrm{mmol} ; \mathrm{M} . \mathrm{O} .: \%$.

\section{Copyrights}

Copyright for this article is retained by the author(s), with first publication rights granted to the journal.

This is an open-access article distributed under the terms and conditions of the Creative Commons Attribution license (http://creativecommons.org/licenses/by/4.0/). 